Japan. J. Trop. Med., Vol. 10, 205-210, 1969

\title{
FIELD TRIALS OF INACTIVATED JAPANESE ENCEPHALITIS VIRUS VACCINE IN HOKKAIDO
}

\author{
MASATSUGU KANAMITSU, NoBUO HASHIMOTO \\ MitSUHIKo KATSURADA AND HIROO KIMURA \\ Department of Hygiene, Sapporo Medical College
}

Great advances were made in the methods of preparation and purification of of inactivated Japanese encephalitis virus vaccine in recent years. Immunizing effect of the purified vaccine for man has also been studied, but most of the studies have been conducted in Honshu, where JE is occurring endemically. Inhabitants of such an endemic area of the disease have mostly had antibody to the virus early in their life, and the antibody modifies serologic response due to the vaccination. Persons without the antibody in the area also are not always exception to this rule, because they include those who have previously had the antibody but have lost it later. Persons living in the area free from JE are presumably the most suitable subjects for the study. Earlier, Miura reported that inhabitants of the northern part of Hokkaido did not have antibody to JE virus. This was reconfirmed later by us. Based of these findings, we conducted the present study in this particular district.

\section{Materials and Methods}

Junior high school students who were borne in the northern part of Hokkaido and have been inhabited there after birth, without experience of living in Honshu, were subjected to the study. They were proved not to have the antibody to JE virus at the serum dilution $1: 5$. Two antigenically different vaccines were employed. One was the vaccine prepared from mouse brains infected with Nakayama$\mathrm{NIH}$ strain of JE virus. It consisted of 3 lots. Other was the vaccine prepared from JaGAr01 strain, in the same manner. Both were vaccines purified highly by treating it with protamine-alcohol or by ultracentrifugation. Subjects were inoculated primarily with $1 \mathrm{ml}$ of the vaccines once, or twice with different intervals of time. One year after the primary vaccination, they received a booster inoculation with the vaccines same to that inoculated primarily. Sera were titrated for neutralizing antibody, using Nakayama-NIH and JaGAr01 strains as antigen, by means of the plaque reduction method. A significant reduction in the number of plaques at the serum dilutions $1: 10$ or greater was taken as positive.

\section{Results}

Fig. 1 demonstrates distributions in the titer of antibody in the groups of subjects inoculated once primarily with different vaccines. The distributions differ greatly with the lot and antigenic properties of the vaccines employed. The mean 
Fig. 1. Antibody Distributions in Man 1 Month After 1 Shot of JE Vaccines Different in the Lot and Antigenicity

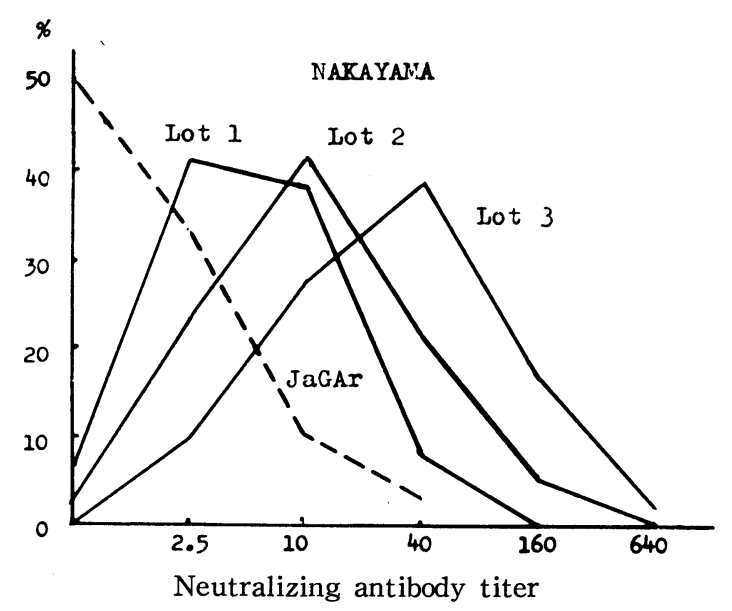

antibody titers of each group are probably the best indicator of immunizing potency of each vaccine for man. The potency was the highest in the lot 3 Nakayama vaccine among the 4 tested, and the lowest in the JaGAr01 vaccine. The order of the potency of vaccines presented in Table 1 agreed with that obtained from the test using mice, except the JaGAr 01 vaccine.

Table 1. Geometric Means of Antibody Titers Produced by Each Vaccine

\begin{tabular}{ccc}
\hline Vaccine & No. of subjects & Mean antibody titer \\
\hline NAKAYAMA & & \\
Lot 1 & 77 & 5.8 \\
Lot 2 & 52 & 10.9 \\
Lot 3 & 72 & 26.6 \\
JaGAr01 & 2.0 \\
\hline
\end{tabular}

Antibody production following primary and booster inoculation with different vaccines were shown in Fig. 2. The antibody produced by one shot of Nakayama vaccines was low. More than half of subjects inoculated with the lot 1 vaccine did not have the antibody. The negative rate of the group which received the lot 2 vaccine was about $30 \%$. Decrease in the antibody titer with elapsing time was remarkable, particularly in the group inoculated with the vaccine of low potency.

Inoculation twice with the same vaccine increased greatly the antibody, independent of its potency, and the antibody was maintained to higher levels for a long time. The effect of booster vaccination performed one year after the primary vaccination was striking. The mean antibody titer reached to $1: 1,000$ or $1: 5,000$, and in individual cases it reached up to $1: 40,000$, one month after the vaccination. It was worthy to note that the antibody titers produced by the booster 
Table 2. Production of Antibodies to the Viruses Homologous and Heterologous to the Vaccines Inoculated

\begin{tabular}{|c|c|c|c|c|c|c|c|c|}
\hline \multirow{3}{*}{$\begin{array}{c}\text { Vaccine } \\
\begin{array}{c}\text { Time of } \\
\text { study }\end{array} \\
\text { Antibody }\end{array}$} & \multicolumn{4}{|c|}{ Nakayama } & \multicolumn{4}{|c|}{ JaGAr } \\
\hline & \multicolumn{2}{|c|}{$\begin{array}{l}\text { One week after } \\
\text { 1st inocul. }\end{array}$} & \multicolumn{2}{|c|}{$\begin{array}{l}\text { One week after } \\
\text { booster inocul. }\end{array}$} & \multicolumn{2}{|c|}{$\begin{array}{l}\text { One week after } \\
\text { 1st inocul. }\end{array}$} & \multicolumn{2}{|c|}{$\begin{array}{l}\text { One week after } \\
\text { booster inocul. }\end{array}$} \\
\hline & Naka. & JaGAr & Naka. & JaGAr & $\mathrm{JaGAr}$ & Naka. & $\mathrm{JaGAr}$ & Naka. \\
\hline$<10$ & 0 & 29 & 0 & 0 & 0 & 5 & 0 . & 0 \\
\hline 10 & 0 & 35 & 0 & 8 & 1 & 5 & 5 & 0 \\
\hline 40 & 33 & 8 & 1 & 49 & 3 & 0 & 0 & 7 \\
\hline 160 & 31 & 0 & 10 & 46 & 1 & 0 & 3 & 4 \\
\hline 640 & 8 & 0 & 53 & 34 & 5 & 0 & 6 & 0 \\
\hline 2560 & 0 & 0 & 36 & 9 & 0 & 0 & 5 & 1 \\
\hline 10240 & 0 & 0 & 31 & 2 & 0 & 0 & 2 & 0 \\
\hline $40960+$ & 0 & 0 & 17 & 0 & 0 & 0 & 0 & 0 \\
\hline Total & 72 & 72 & 148 & 148 & 10 & 10 & 16 & 16 \\
\hline Mean titer & 98 & 6.3 & 2250 & 150 & 158 & 5 & 1154 & 51 \\
\hline
\end{tabular}

Table 3. Homologous and Heterologous Antibody Responses Following Booster Vaccination

\begin{tabular}{|c|c|c|c|c|c|}
\hline \multirow{2}{*}{ Vaccine } & \multirow{3}{*}{ No. } & \multicolumn{4}{|c|}{ Antibody } \\
\hline & & \multicolumn{2}{|c|}{ Nakayama } & \multicolumn{2}{|c|}{ JaGAr } \\
\hline Primary & & Pre. & Post & Pre. & Post \\
\hline Nakayama-Nakayama & 15 & \multicolumn{2}{|c|}{$4.1(79 \times)^{326}$} & \multicolumn{2}{|c|}{$(33 \times)$} \\
\hline Nakayama-JaGAr01 & 15 & \multicolumn{2}{|c|}{$(128 \times)$} & 1.5 & )$^{126}$ \\
\hline JaGAr01-JaGAr01 & 19 & \multicolumn{2}{|c|}{$(25 \times)$} & \multicolumn{2}{|c|}{$(123 \times)$} \\
\hline JaGAr-Nakayama01 & 17 & \multicolumn{2}{|c|}{$(24 \times)$} & 8.3 & 372 \\
\hline
\end{tabular}

* Fold rise.

that the booster effect. was greater for the antibody to Nakayama virus in the group inoculated with Nakayama vaccine at the time of both primary and booster vaccination. Same enhanced effect was seen for the antibody to JaGAr virus in the group inoculated with JaGAr01 vaccine at both time. However, in the groups inoculated with different vaccines at the time of primary and booster inoculations, the booster effect was greater always for the antibody to the virus of the vaccine given primarily. All subjects employed for the present study were those who have never been exposed to $\mathrm{JE}$ virus in past time. Accordingly, the primary inoculation with $\mathrm{JE}$ vaccine would become the first experience of receiving antigenic stimulation of $\mathrm{JE}$ virus. Above-mentioned result seemed to be similar to the 
Fig. 2. Antibody Production Following Primary and Booster Inoculations with Different Vaccines
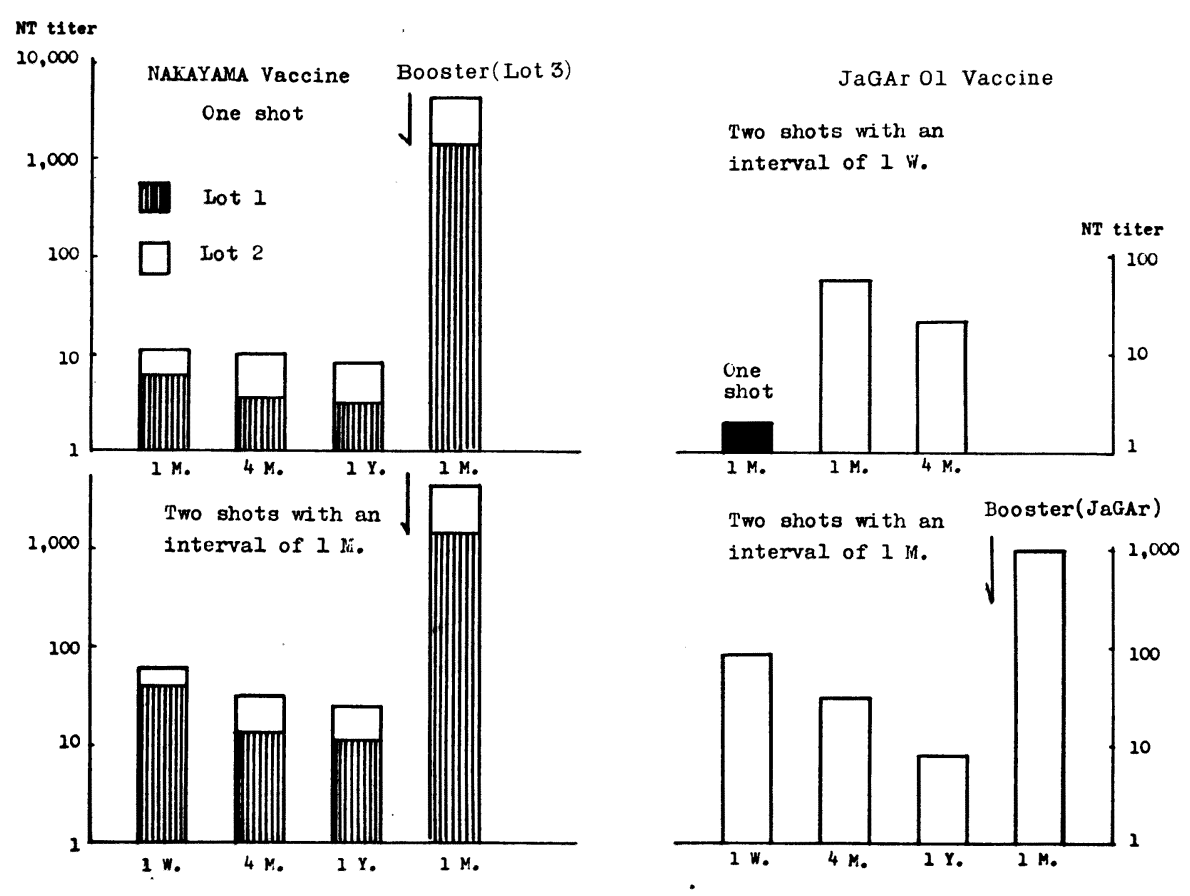

vaccination did not differ greatly by the number of times of primary vaccination.

The immunizing potency of JaGAr 01 vaccine was low, as mentioned above, but inoculation twice of the vaccine with different intervals of time increased the antibody up to the levels comparable to that obtained from Nakayama vaccine with high potency. The booster effect of JaGAr 01 vaccine was also remarkable.

The two viruses of Nakayama and JaGAr 01 strains contain strain-specific antigen, besides antigens common to both strains. This brings out the question whether Nakayama vaccine gives immunity to prevent effectively JaGAr 01 virus infection, and vice versa. We studied this problem from the viewpoint of production of antibody to the virus heterologous to that of vaccine inoculated. Table 2 showed the result. An antibody titer of $1: 10$ is regarded as the minimal level requested for preventing JE virus infection by mosquito bite. Two shots of each vaccine increased antibody to homologous visus to the level, but about half to the vaccinated failed to have the antibody to heterologous virus. Booster vaccination was effective for producing the heterologous antibody, as well as the homologous antibody.

The above-mentioned study of booster vaccination was conducted always in such a manner in which subjects were boosted with the vaccine same to that inoculated primarily. Next, we boosted groups of subjects with a vaccine heterologous to that given primarily for them, to compare the booster effect with that of the previous study. The result was presented in Table 3. It was an expected finding 
phenomenon of original antigenic sin known in influenza.

Finally, we studied physico-chemical properties of the antibody produced by the vaccination. Serum fractions were obtained by filtering sera through Sephadex G-200 gel column. Another part of same serum was tested for the sensitivity to 2-mercaptoethanol. Representative results were shown in Fig. 3. Virus-neutralizing activity of serum collected on the 14th day of primary vaccination was found to be located exclusively in the $19 \mathrm{~S}$ macroglobulin fractions. The activity was detectable in the same serum fractions still on the 22nd day and later. However, the activity came to appearance, at the same time, in the $7 \mathrm{~S}$ globulin fractions, although the activity of the fractions was small. One year after the vaccination,

Fig. 3. Sephadex G-200 Fractionation of Sera Collected from Same Person After Primary and Booster Inoculation with Nakayama Vaccine
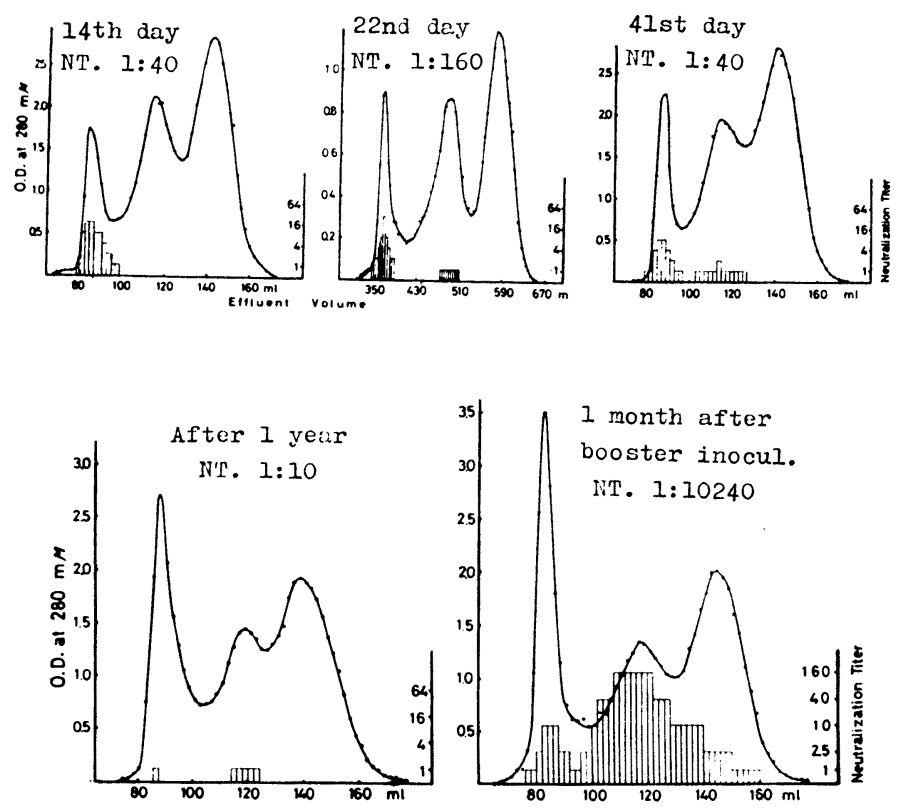

the virus-neutralizing activity was greatly reduced in both fractions. Booster vaccination increased the activity of serum to the titer of $1: 10,240$. It is clear that the increase was due largely to increase in the activity of the $7 \mathrm{~S}$ globulin fractions. The result agreed also with that of the study using 2-ME.

\section{Discussion and Conclusion}

The inactivated $\mathrm{JE}$ virus vaccines employed in the study were thought to be effective for man, if he received the vaccination twice with intervals of 1 week or 1 month. But, booster vaccination is necessary to maintain the antibody to high levels for a long time. Selection of virus strain is of importance in the production of $\mathrm{JE}$ virus vaccine. In Japan, most of $\mathrm{JE}$ viruses isolated currently 
were similar antigenically to JaGAr 01 strain. From the fact, production of JaGAr 01 vaccine with high immunizing potency has long been requested. The JaGAr 01 vaccine employed to the present study is thought to grant the request. The effect of booster inoculation with a vaccine heterologous to those inoculated primarily on antibody response was of interest. The result presumably contribute to antigenic classification of JE virus. Physicochemical properties of the antibody produced by the inactivated $\mathrm{JE}$ virus vaccine were similar in principle to those obtained from same kind of vaccines prepared from other viruses, but is differs somewhat from the result of $\mathrm{JE}$ patients. 